Indonesian Journal of EFL and Linguistics

Vol. 4 No. 2, 2019

eISSN: 2503-4197, pISSN: 2527-5070

www. indonesian-efl-journal.org

\title{
Integrating "Daily Learn English Application" to Teach Speaking Skill in EFL Classroom
}

\author{
Nina Julia Anugrah \\ Sebelas Maret University \\ email: ninajulia36@gmail.com \\ Sumardi \\ Sebelas Maret University \\ email: arif_sumardi74@yahoo.co.id \\ Slamet Supriyadi \\ Sebelas Maret University \\ email: pripus.lppmuns@yahoo.co.id
}

\begin{abstract}
:
The generation who is raised in the digital world has come to believe learning meant to be loud, colorful, and energetic. Teachers who want to reach out to this generation need to use media to grab attention. Teachers must be adaptive, which means that they must begin to believe that integrating technology is an effective way of teaching. This research is aimed at investigating teacher's belief and practice on the integration of "Daily Learn English" Application to teach speaking skill in EFL classroom. To reach the objective, a case study on an individual teacher was used in this research. Data collection techniques of the research were Interview and observation. The result indicated that the teacher believes that integrating "Daily Learn English" Application could facilitate the teacher in creating an active, creative and fun teaching-learning process and there was no discrepancy between belief and practice as the teacher has been integrating this application in the classroom.

Keywords: "Daily Learn English" Application, Teacher's Belief and Practice, Teaching Speaking, EFL Classroom
\end{abstract}


Nina Julia Anugrah, Sumardi and Slamet Supriyadi

\section{INTRODUCTION}

There is clear evidence that all actions taken by teachers in the class are influenced by their beliefs and that this plays a key role in understanding teachers' behavior. Teachers' beliefs can be a guideline for teachers to adopt their classroom practices and to overcome everyday language teaching problems (Fauziati, 2015). Furthermore, Richardson (1996) emphasizes that what the teacher does in class is a form of what he or she believes, the relationship between beliefs and practices is interactive. According Raymond (1997) defines beliefs as a personal judgment formed from experience. Beliefs have an important role in teacher classroom practice and their professional development. Kuzborska (2011) explains that what the teacher does in class depending on the beliefs they have about teaching and learning languages. Williams \& Burden (2004) also assert that teacher beliefs have a big influence on prepare their classes, the types of decisions they make and their general classroom practice more than their knowledge of it.

$21^{\text {st }}$-century era requires people to use technology in everyday life, including in education. To prepare competitive human resources, integrating technology into the classroom is a necessity. Technology provides many advantages for learning English, all materials can be accessed quickly, easily, and readily available, and also to enhance student's interest in learning English. Students cannot be effective tomorrow if they are trained in yesterday's methods, no matter how sophisticated the tools are, the teacher is still the most influential "tool" in the classroom. The rapid growth of technology has naturally affected every aspect of the language teaching process. According to Altun (2015) Technology has positive effects on teaching English to raise students' motivation and language awareness. Williams \& Burden (2004) add teachers must be adaptive which means that they must begin to believe that using technology in the classroom is an effective way to build an active classroom atmosphere.

The teacher can choose technology that can be used according to pedagogical methods and language skills in teaching. M-learning is a form or learning model that utilizes the capabilities of mobile devices. As explained by Guy (2009) M-learning as electronic learning (e-learning) through mobile computing devices. Mobile phones have a potential of improving the teaching and learning processes as the tools are cheap compared to other ICTs which can be used for teaching and learning. Moreover, the utilization of Mobile Application in the teaching and learning activities in $21^{\text {st }}$-century learning demands the teacher to get used to it. One of the mobile applications that can be used to support teachers in the teaching English is 'Daily Learn English' application. This application provides various features that can be used to facilitate learners in speaking practice, such as video lesson, audio lesson, essential words, essential phrase and speaking practice which many has several materials in it and can be used offline. 
A number of researches related to mobile learning in the classroom have been conducted by Yudhiantara \& Nasir (2017) showed that students had positive attitude toward mobile phone to support classroom process. Another study, Syafitri, et (2018) focused on implementing Powtoon as a media to improve the students' pronunciation in speaking class. Finding revealed that improving the students' pronunciation in speaking using Powtoon was successful because the motivation, attention, and interest of the students' improved.After reading previous research, none of them specifically discussed to what extent teachers really utilize mobile applications in EFL classroom. Therefore, this research tries to reveal teacher's beliefs and practices on integrating mobile application in teaching speaking skills as well as to what extent the application is implemented.

To sum up, the researcher identifies the problems as follow:

1.1 What are teacher's beliefs on integrating "Daily Learn English Application" to teach speaking skill?

1.2 How are "Daily Learn English Application" implemented in teaching speaking skills?

\section{LITERATURE REVIEW}

\subsection{Teachers' Beliefs in ELT}

Teachers can hold beliefs about every aspect of their lives that might be related to the context of general education, the institutions they work in, the learning process, students and even their personal lives. Williams \& Burden (2004) explain teachers' beliefs about what learning will affect everything they do in class. It is very important for teachers to first understand their own theoretical perspectives. If teachers are educators they will continue to re-evaluate based on new knowledge or about how language is learned, or about education as a whole.

Kleinsasser, et al (1995) provide guideline for English teachers for the investigation of teachers' belief which includes: Belief about English, English is international language and English is compulsory school subject to learn, teacher believe that English is important to teach. Belief about learning, teachers believe kinds of learning outcomes that learners want to achieve. Belief about teaching: teaching is very personal activity. Teachers have their own assumption about effective teaching. Belief about Program and the Curriculum, teachers have specific belief toward program and curriculum in their institution. The last is Belief about Language Teaching as a Profession; it means teachers have a sense of professionalism towards their job.

\subsection{Mobile Application}

MALL is a language teaching approach that is assisted through the use of handheld mobile devices. It can be considered a solution to language learning constraints in terms of time and place. In MALL students do not need to sit in the classroom or on 
the computer to get learning material. Mobile devices are increasingly developing into tools for education and language learning, and all users from teachers or students are getting used to this environment to make education everywhere as much as possible. As soon as mobile phones become an important part of our lives, there is a need to use them in the task of learning languages.

Mobile phone is one type of mobile devices that have many applications as media to help the teaching-learning activities in EFL classrooms. One of the mobile applications that teacher used for support teaching and learning process is 'Daily Learn English'. It is one of the mobile applications used by the teacher as a media to facilitate her in teaching speaking skill for EFL learners. Teaching speaking skills using 'Daily Learn English' application can motivate EFL learners learning to speak. Teaching using this application will also help the teacher to shorten the time and facilitate the teacher in finding teaching material. This application provides various features that can be used to facilitate learners in speaking practice, such as video lesson, audio lesson, essential words, essential phrase and speaking practice which many has several materials in it and can be used offline. So the teacher does not need to prepare or download the material herself. As an example, in the 'video lesson' feature, it contains several short 3-minutes English conversation videos represent the real practice of conversation in real condition by the native speaker. Then, in 'audio lesson', it contains several short conversations with specific characters that can be used by the teacher to ask her learners to practice speaking themselves to improve their speaking skills.

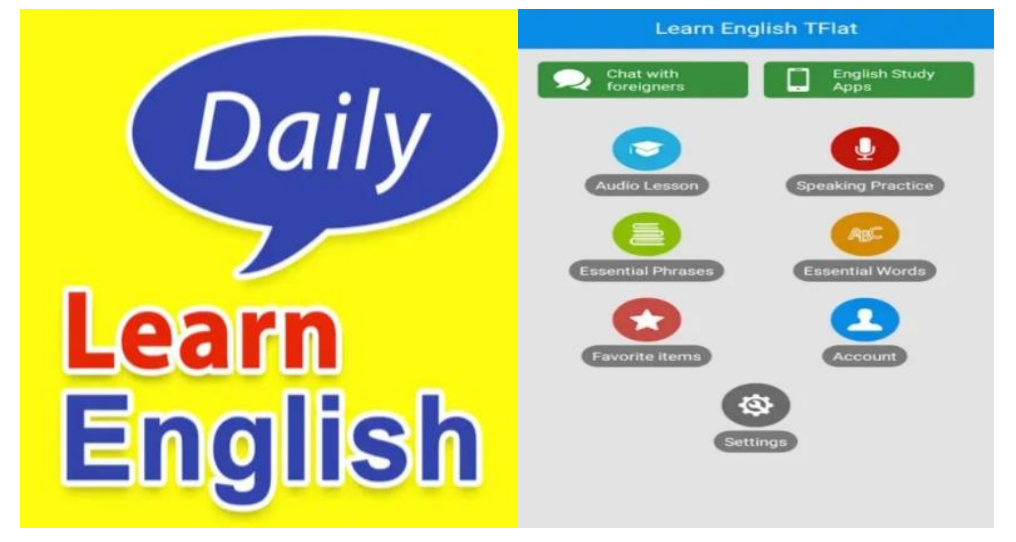

Figure 1. Daily Learn English Application

\section{RESEARCH METHODOLOGY}

A qualitative case study is research which tends to explore depth phenomenon and provide the best understanding of a research problem by revealing the general characteristic of issues. In line with the explanation above, this research employs a case study to explore the teacher's belief and practice on integrating "Daily Learn English" application to teach speaking skill in EFL classroom. 
A single English teacher from one of Private Vocational School in Karanganyar, Central Java, Indonesia was purposively selected as the research subject; it was found that the teacher in that school has been integrating this application in her class. The rationale of choosing this design and the teacher is since this study intends to get a deep understanding on teacher's belief and practice on integrating mobile application in EFL classroom as well as to what extent the application is applied. Therefore, the investigation was targeted only to an English teacher who can give data to answer the research questions.

The research employed classroom observation and interview to allow the researcher to gather authentic data and to have a full idea about the belief behind the teacher that influences the practice.

The observation was carried out three times during the teaching and learning process using Daily Learn English Application, especially in speaking skills. Next, the data collected is analyzed and more analytic questions are designed to be asked in subsequent interviews.

The data were analyzed using the interactive model by Miles, Huberman, \& Saldana (2014). Those data were collected through interview and observation then they were transformed into data condensation stage by writing interview transcript, coding and generating categories based on the research questions. Then, they were displayed in a word description and obtained drawing and verifying conclusions as a result.

\section{FINDINGS}

This research showed the information related to teachers' beliefs and her practices on integrating "Daily Learn English" Application to teach speaking skill in EFL classroom. The result of the interview and observation were displayed here.

\subsection{Teacher's Belief in Integrating "Daily Learn English" Application to Teach Speaking Skill}

\subsubsection{Teacher's Definition of Mobile Application}

The teacher has been integrating mobile learning in the classroom. In teaching speaking the teacher implemented the use of mobile application. The first issue is what the participant's definition about mobile application. Data are obtained from interview to the teacher by asking her a question about what mobile application according to her.

In my opinion a mobile application is an application that allows us to do mobility using equipment such as PDAs, cellular phones or Smartphones. For example, applications that are embedded in our smartphones. By using a mobile application, we can easily do a variety of activities ranging from studying, doing office work, browsing, entertainment, selling, and so forth\}. 
From the response above, the teacher understands about the definition of mobile application. The point is that mobile applications are defined applications that are embedded on mobile phones, as explained by the teacher above. Then, the teacher also understands that mobile applications have benefits, she said that the mobile application can facilitate us in carrying out various activities, as a teacher, she said that mobile application can facilitate her teaching in class, looking for some materials and media of teaching and learning, because she can download various English learning applications on the smartphone. The teacher also explained that the mobile application is useful not only in teaching activities but also it can be used as entertainment when having free time, looking for information on social media, even it can be used as a selling tool of business people, and many other benefits of mobile applications that make it easy for us today.

\subsubsection{The Importance of Technology and Mobile Application}

The belief behind the teacher about mobile application integration will, of course, influence the process of teaching-learning in the classroom. From the result of the interview, the participant was asked about what she thinks of technology in education. The teacher described her beliefs about teachers must understand technology to face the challenges of 21 st century learning.

Nowadays technology is developing rapidly. Various technologies become things that are always used and even become life mates. In my opinion, education is adapted to the development of the times. Teachers are professions that will not be replaced by technology, but teachers must be able to deal with change. So, why do teachers have to understand technology? In the 21st century, professional teachers are not only required to have pedagogic competencies but also required to have professional competencies, one of them in technology, because using technology will give rise to teacher and student creativity and increase students' motivation in learning.

As depicted in the above transcript, there was some information that could be discerned from the remark given by the teacher. Technology will continue to develop. If someone does not want to take advantage of existing technology, then he will be left behind. Technology is very influential in aspects of human life and plays a role in the life of the wider community, especially the role of technology in the field of education. In education itself, technology now has its own role in the learning activities. She believes that the presence of technology, especially the internet in education has a big influence on teachers and the way teachers teach their students in the classroom. Also, she believes that teachers who are better prepared and aware of technological advances in education will motivate them to be more creative in preparing and creating content that is interesting for students. So that learning becomes more enjoyable and learning objectives can be maximally achieved. 
In line with this, the teacher also believes that integrating Mobile Application in her teaching can bring many benefits. The teacher explained her view about the eases of integrating Mobile Application.

By following the digital era in the implementation of teaching, I believe that it will bring changes in classroom learning. The use of Mobile Application as a learning media will make the teaching and learning process effective and efficient because it makes me easier to obtain or deliver subject matter, then it helps increase students' understanding because the presentation of the material is more interesting.

What the teachers thought about the importance of technology in education is following the regulation of the Indonesian Ministry of Education No. 38 year 2008 about the implementation of information and communication technology in the educational system. It means that the participant aware to utilize technology in the learning process. The teacher's statement supported that mobile application can help classroom activities and learning process. The mobile application can facilitate her in delivering the material and make students more interested in learning English, because she make use of something that is familiar with students. This is supported by prior research by Yudhiantara \& Nasir (2017) mobile phones provides benefits that can be obtained by students in supporting classroom activities and learning English.

\subsubsection{Reasons to Use Mobile Application}

The next issue relating to teacher's beliefs on integrating "Daily Learn English" Application to teach speaking is the teacher's reasons to use this application. The teacher explained what influences her to integrate Mobile Application in the classroom.

At this time technology is a part of our lives, especially millennials. My students sometimes talk about their idols like Vloggers, YouTubers, Gamers, etc. - which encouraged me to make my lessons acceptable to students. As teachers, we are demanded to be creative, because in today's era students are more modern than teachers. Therefore, as a teacher, I try to find something new that can make students motivated to learn English especially in speaking.

From the response above, it can be inferred that teacher saw the advantages of mobile application as her reasons to use it. Some advantages are proposed by Kumar (2013) that stated the advantages of using mobile learning, namely students get stimulated in learning, related more closely to students' needs and support more creative teaching approaches. Therefore, as a teacher who teaches millennial students who are sometimes more modern than their teacher, this is one of the reasons why she chooses to teach using a mobile application. 
Nina Julia Anugrah, Sumardi and Slamet Supriyadi

In addition, the teacher believes that integrating "Daily Learn English" Application in teaching speaking will be very helpful since the students can learn not only the theory but also the real practice of conversation in a real condition by the native speaker. She explains:

This application provides various features that can be used to facilitate students in speaking exercises, such as video lessons, audio lessons, essential words, essential phrases and speaking practice that has a lot of material in them. I have tried other applications to teach grammar or listening, students were less enthusiastic, they said bored. So I tried using an application for teaching speaking, apparently, they preferred this one.

The statement above explains that the application has many features that can be used by students to learn English, especially in speaking skills. These features have their respective functions, for example in the video lesson feature contains a variety of videos with various topics about daily conversation. In audio lesson features, there are various common expressions and sentences in conversation. Then, in speaking feature, there are hundreds of common words for conversation, and so forth. Also, this application was very helpful for the teacher in increasing the motivation of students and helping her in explaining the material, because all students already have a smartphone. Previously, the teacher had also used other applications in teaching grammar and listening, but apparently the children felt less interested. She said that the selection of interesting applications and creating a comfortable classroom atmosphere were also needed in the teaching and learning process.

\subsubsection{The Usefulness of the Mobile Application}

Furthermore, the issue of teacher's beliefs on integrating mobile application to teach speaking is the usefulness of the mobile application. Teacher believes that mobile application is useful in teaching target language. The students showed positive attitude toward the mobile application. Data obtained from the interview showed that she considers some points.

The use of mobile application is very helpful in teaching speaking since it requires students' communication skill. By using the application, in this course I use "Daily Learn English Application" in teaching speaking, the students can learn not only the way of speaking but also the gesture, intonation, etc. through the video lesson by the native speaker in a real situation. Moreover, the students can check the appropriateness of their pronunciation that will be graded by the application through feature 'speaking'. Therefore, students can be actively participating in learning activity since the current style of teaching refers to students-center. 
The teacher in the above transcript viewed that the mobile application is useful. She believes that the use of this application in teaching speaking can be very helpful to encourage the students to speak up and learn from the native speaker about how to produce words or sentences in a conversation and students can also actively participate in class. For influence on students' speaking skills, this is more focused on aspects of pronunciation, because in the application provides an assessment of how to pronounce words, if their pronunciation is good then they will get five stars, if their pronunciation is less good then they will get fewer stars. So students can judge their own pronunciation and they know what the correct pronunciation is. During observation in class, the researcher also saw that students were very enthusiastic about using these features.

\subsubsection{The Role of Teacher in the Classroom}

The last issues relating to teacher's beliefs on integrating mobile application to teach speaking is the role of teacher in the classroom. This is a representation of her belief believing that the teacher's role should be as a facilitator. Interestingly, her belief is reflected in the way she taught speaking

In integrating "Daily Learn English" Application in learning, my role is as a facilitator. Students participate more, such as they must download the application first, then work together with groups or individuals. My task is to explain how to use the application and then monitor them when using the application.

As a facilitator, she asked students to download the application that they would use at the previous meeting, and then the teacher explained how to use the application and introduced all the features available in the application. During learning activities, the teacher asked students to be active in learning by forming several groups. She also approached each group to monitor students and help students whenever needed.

\subsection{Teacher's Practices in Integrating "Daily Learn English Application" to Teach Speaking Skill in EFL Classroom}

In this issue, the researcher observes the teacher and students activity during the class. The observation is done by recording the teaching and learning process and taking note of the activity. The observation shows that the teacher does integrate Mobile Application in teaching English speaking conversation by using "Daily Learn English" Application. The activity of speaking class was designed as effective as possible where the teacher used the student-center based learning. The following steps of teaching activity were gotten as the result of classroom observation in three meetings.

1. The teacher introduced "Daily Learn English" as a mobile application of speaking skill which will be used as the learning media. Actually, all of the 
Nina Julia Anugrah, Sumardi and Slamet Supriyadi

students had downloaded the application in their smartphone as the instruction from the teacher. Thus, they have been familiar with the features of the application that consists of video lesson, audio lesson, speaking, essential phrases, and essential words.

2. The teacher began the class by discussing the previous topic and encouraged the students to be more confident in speaking. Afterwards, the teacher introduced the new topic that will be learned that day. During three meetings observation, the class was discussing speaking conversation in the topic of "asking and giving direction".

3. The teacher explained how to ask or give direction and mentioned the crucial components of conversation that must learn such as the intonation, gesture, etc.

4. The teacher instructed the students for accessing their "Daily Learn English" application and found the topic. As the power and the advantage of this application, it provided various English conversation topics with the short video lesson of each which represent the real practice of conversation in a real condition by the native speaker.

5. As the instruction, the teacher told to students to find the topic in the video lesson. There were various themes in the list of video, due to the level of students who are still in the beginner learner of English, the students were asked to choose "Basic English Conversation 1". There are more than twenty videos provided by the application with various topics of daily conversation. Regarding the topic that day, the students chose the twelfth topic about "Directions to the toilet"

6. The students then work with their partner to learn the conversation pattern from watching the video about directions to the toilet. Not only video lesson, but the students also can learn the appropriate way to pronounce the words using the feature "speaking". In this feature, there are hundreds of common words for conversation. The students can hear how the pronunciation is by listening to it carefully, after that they can practice by recording their voice in pronouncing the words that will be graded by the star level.

7. The teacher asks students to open the "audio lesson" feature and the students listen to the conversation in the feature and then practice with their partners. In audio lesson features, there are various common expressions and sentences in conversation. By choosing the detail in the list of topics, the students can hear the conversation to practice their listening skill also.

8. Furthermore, the teacher divides students into groups and asks them to make a conversation that concerns the theme of "asking and giving information" by using references from several phrases in the "essential phrases" feature. By using this feature, the students also can learn the pronunciation and the intonation to say the expression.

9. Afterward, each group was asked to come in front of the class and practice the conversation of the given topic that has been practiced. As the teaching-learning 
media, this mobile application is used as the tool to improve students' motivation to speak and encourage them to be more confident. However, for the assessment, the teacher still does it herself.

10. While the students were performing the conversation in front of the class, the teacher assesses their ability personally by using some speaking criteria. Based on the interview, the criteria used by the teacher are the fluency, the structure, the pronunciation, and gesture.

In integrating Mobile Application to teach speaking skill in EFL classroom, the teacher played the role as the facilitator. She guides the students in understanding the video lesson from the application by giving a brief supporting explanation about the intonation, gesture and pronunciation. During the practice time, some students were asking the teachers and they did a small discussion. After all of the groups were ready, they were randomly come in front of the class to perform a conversation they have learned. On the corner, the teacher watched the students' performance, asked questions related to the conversation made by them and assessed the students by using some fix criteria.

\section{DISCUSSION}

This section extends to discuss all the data having been garnered, displayed and analyzed in prior. There were two major scopes of findings that were addressed. They entailed teacher's beliefs and teacher's practices on integrating Mobile Application to teach speaking skill in EFL classroom. The results showed that the teacher has strong belief toward the use of mobile application in teaching speaking reflected her ways of teaching. At this point, her ways of teaching depend on how she believes about the definition of mobile application, the importance of technology, especially mobile application, what her reasons for using the mobile application, what criteria for selecting the mobile application that she choose, what particular mobile application she prefers, and her role in integrating the application.

The researcher identifies one aspect that shapes teacher's beliefs. The identified aspect is teacher's understanding of mobile application. From the findings, teachers believe that mobile application is an application that allows us to do mobility using equipment such as PDAs, cellular phones or Smartphones. Mobile applications are derived from the words of application and mobile. In terms of application is a readymade program designed to carry out a function for the user or other applications and can be used by the intended target while mobile can be interpreted as a move from one place to another. So a mobile application can be interpreted as an application program that can be run or used even if the user moves from one place to another and has a small size. This mobile application can be accessed via wireless devices, pagers, PDAs, cellular phones, smartphones, and similar devices. It is believed that teacher's understanding of the term of mobile application has been the main aspect that shaped their beliefs. 
The teacher's beliefs about technology and mobile applications in teaching are related to teaching practices. It can be seen from the way she believes that teachers must understand technology to face the challenges of $21^{\text {st }}$-century learning because using technology will give rise to teacher and student creativity and increase students' motivation in learning. In line with this, the teacher believes that the use of Mobile Application as a learning media will make the teaching and learning process effective and efficient. The teacher's belief in technology in general and mobile application, in particular, is related to teaching practices in which she uses the Daily English Learning Application as a powerful media. This is supported by O'Bannon \& Thomas (2014) who stated that mobile learning is about the activities, which allow students to be more productive. In addition, Mirzajani, et al (2006) stated that Mobile learning allows students to study anywhere, whether in or outside the classroom.

Further, the teacher's belief about her reasons in using the mobile application, the result revealed that the students are millennial which encourages her to make the lesson acceptable to the students. She believes her students more modern than her, so she demanded to be creative and innovative; she uses an application to make students motivated in learning English, especially speaking. In line with previous research by Ekmekçi (2016) stated that today's students are considered digital-native who are difficult to motivate to learn, and therefore they need a modern technology that can be used effectively in class.

Next, the teacher's beliefs about the application that has been used in teaching speaking which helps encourage students to speak up. Using the application, in this case, the teacher use "Daily Learn English Application" in teaching speaking, the students can learn not only the way of speaking but also the gesture, intonation, etc. In addition, learning to speak from video or audio recorded by native speakers will familiarize students with correct pronunciation. Also, integrating some features in the application with group work and role playing activities indicates her belief that speaking will be better learned when it is more practiced. In line with prior research by Syafitri et al., (2018) that Implementation of Powtoon application in teaching speaking skills, especially in pronunciation can make motivation, attention, interest, and student participation increase. As it is supported by Morris, et al (2016) mobile technology can upgrade students' motivation and change teachers' teaching strategies from teacher-centered to student-centered.

Besides identifying teacher's beliefs, the researcher also describes how the mobile application is implemented in teaching speaking. Borg (2003) says that teachers' beliefs strongly shape teacher's instructional practices, and subsequently the learning opportunities that learners receive. The researcher describes that teacher has well-managed in teaching speaking by using mobile application. She makes use of mobile application (in this case, Daily Learn English Application) to train students' speaking skills and improved students' motivation to learn speaking. In 
addition, by analyzing student activities when taught using the application, for example when they do role-play in front of the class with their partners, it shows that this application can upgrade students' motivation to learn to speak and that is same with previous research conducted by Akhiar, et al (2017) that revealed students' high positive attitudes and views towards using mobile application in improving their English skill. In conclusion, a belief about "Daily Learn English" application is truly connected with teaching practices and thus this research supports some previous research. In the other words, this is categorized into a good implementation of technology as the teacher believes on integrating "Daily Learn English" Application in teaching as well as the practices are in line with the belief about Mobile Application itself.

\section{CONCLUSION}

In this paper, the teacher's beliefs about "Daily Learn English" Application and her practice in the classroom have been presented based on classroom observation and interview. She believes that Mobile Application is very important to be implemented in the teaching and learning activities as it will give advantages for teachers, students, as well as educational development in Indonesia. Students feel happier because they use what they are familiar with. In addition, the teacher also believes that "Daily Learn English" application helps her to shorten the time and facilitate her in finding teaching materials. These beliefs are connected to teaching practices as evidenced by observation in class. It seems that the fact that the integration of mobile applications is influenced by the belief of the teacher itself. This research implies some suggestions for EFL teacher. First, it is necessary for teachers to equip themselves with mobile-assisted language learning training, seminar, or workshop before they use it in the classroom further they are confident in using it. Second, teachers should care for their students' motivation and participation by demonstrating proper personal and teaching behavior integrated with mobile learning in the classroom.

\section{REFERENCES}

Akhiar, A., Mydin, A. A., \& Kasuma, S. A. A. (2017). Students' perceptions and attitudes towards the use of Instagram in English language writing. Malaysian Journal of Learning and Instruction, (Specialissue), 47-72.

Altun, M. (2015). The Integration of Technology into Foreign Language Teaching. International Journal on New Trends in Education and Their, 6(1), 8. Retrieved from www.ijonte.org

Borg, S. (2003). Teacher cognition in language teaching: A review of research on what language teachers think, know, believe, and do. Language Teaching, 36(2), 81-109. https://doi.org/10.1017/S0261444803001903

Ekmekçi, E. (2016). Integrating Edmodo into Foreign Language Classes as an Assessment Tool. Participatory Educational Research, spil6(1), 1-11. 
Nina Julia Anugrah, Sumardi and Slamet Supriyadi

https://doi.org/10.17275/per.16.spi.1.1

Fauziati, E. (2015). Teaching English as a Foreign Language: Principles and Practice. Surakarta: Era Pustaka Utama.

Guy, R. (2009). The Evolution of Mobile Teaching and Learning. California: Informing Science Press.

Hassan Mirzajani, Rosnaini Mahmud, Ahmad Fauzi Mohd Ayub, \& Wong, S. L. (2006). Teachers' acceptance of ICT and ints integration in the classroom. Quality Assurance in Education, 14(3), 251-267. https://doi.org/http://dx.doi.org/10.1108/QAE-11-2012-0046

Kleinsasser, R. C., Richards, J. C., \& Lockhart, C. (1995). Reflective Teaching in Second Language Classrooms. In The Modern Language Journal Vol. 79 (1). https://doi.org/10.2307/329404

Kumar, S. (2013). M-Learning: A New Learning Paradigm. International Journal on New Trends in Education and Their Implications, 4(2), 24-34.

Kuzborska, I. (2011). Links between teachers' beliefs and practices and research on reading. Reading in a Foreign Language, 23(1), 102.

Miles, M. B., Huberman, A. M., \& Saldana, J. (2014). Qualitative Data Analysis Amethods Sourcebook (3rd ed.). USA: Sage Publications, Inc.

Morris, N. P., Lambe, J., Ciccone, J., \& Swinnerton, B. (2016). Mobile technology: students perceived benefits of apps for learning neuroanatomy. Journal of Computer Assisted Learning, 32(5), 430-442. https://doi.org/10.1111/jcal.12144

O'Bannon, B. W., \& Thomas, K. (2014). Teacher perceptions of using mobile phones in the classroom: Age matters! Computers and Education, 74, 15-25. https://doi.org/10.1016/j.compedu.2014.01.006

Raymond, A. M. (1997). Inconsistency between a Beginning Elementary School Teacher's Mathematics Beliefs and Teaching Practice. Journal for Research in Mathematics Education, 28(5), 550-567.

Richardson, V. (1996). The role of attitudes and beliefs in learning to teach (In J.Sikul). Newyork: Macmilan: Handbook of Research on Teacher Education.

Syafitri, A., Asib, A., \& Sumardi, S. (2018). An Applicatin of Powtoon as a Digital Medium: Enhancing Students' Pronounciation in Speaking. Journal of Multicultural and Multireligious 5 (2). 295-317.

Williams, M., \& Burden, R. (2004). Psycology for language teachers.TESOL 33(1). 235.

Yudhiantara, R., \& Nasir, I. A. (2017). Toward Mobile-Assisted Language Learning (MALL): Reaping Mobile Phone Benefits in Classroom Activities. Register Journal, 10(1), 12. https://doi.org/10.18326/rgt.v10i1.813 